\title{
Allozyme polymorphism in isolated populations of the moth Coenophila subrosea (Lepidoptera: Noctuidae) from three Central European peat bogs
}

\author{
JAN ŠULA and KAREL SPITZER \\ Institute of Entomology, Czech Academy of Sciences, Branišovská 31, 37005 České Budějovice, Czech Republic; \\ e-mail: sula@entu.cas.cz; spitzer@entu.cas.cz
}

Key words. Noctuidae, Coenophila subrosea, allozyme variation, population genetics, isolated peat bogs, tyrphobionts, conservation

Abstract. Allozyme polymorphism was investigated in adult males of the stenotopic peat bog (tyrphobiontic) noctuid moth, Coenophila subrosea Stephens, from three isolated peat bog localities in Austria (Styria) and Czech Republic (South and North Bohemia). Of the eighteen enzyme loci examined, twelve were polymorphic and six monomorphic. Significant deviations of genotype frequencies from Hardy-Weinberg equilibrium were observed at about one third of polymorphic loci within the populations. The average heterozygosities for the populations from three geographically distinct localities ranged from 0.192 to 0.245 , and $61 \%$ of the loci were polymorphic. The $\mathrm{F}_{\mathrm{ST}}$ mean value of 0.0675 was higher than that found in most other Lepidoptera. The genetic distances based on allozyme heterozygosity ranged from 0.019 to 0.051 , with the population from South Bohemia being the most distant. The genetic distances and $\mathrm{F}_{\mathrm{ST}}$ values do not reflect the geographic distances between the populations. Morphometric analysis revealed a difference between the Austrian Pürgschachen Moor and Bohemian populations. These isolated relict peat bogs are habitat islands inhabited by unique "geographical races" of tyrphobiontic taxa.

\section{INTRODUCTION}

Accompanying the fragmentation and destruction of natural landscapes in Central Europe, there has been a simultaneous decline in the number and/or size of many animal and plant populations. Therefore, preserving biodiversity is an important task. Attention has been mainly focused upon relict endangered species of unique natural habitats, e.g. insects, many of them butterflies and moths. The rosy marsh moth, Coenophila subrosea (Stephens, 1829), is known to be closely associated with peat bogs in temperate and southern boreal zones. It is an oligophagous species associated mainly with Myrica gale (in British Isles) and several other alternative ericaceous bog food plants, e.g. Andromeda polifolia (Tillotson \& Spitzer, 1998). Several isolated populations have been recorded in Europe outside Fennoscandia (Spitzer \& Novák, 1969; Mikkola \& Spitzer, 1983). This boreal moth is a very characteristic tyrphobiontic species. All tyrphobiontic species (tyrphobionts) are stenotopic, usually boreal or subarctic faunal components, and obligatorily associated with peat bogs (Warnecke 1926; Peus 1932; Mikkola \& Spitzer 1983). The bionomics and Palaearctic distribution of $C$. subrosea were recently reviewed by Tillotson \& Spitzer (1998). To develop an effective conservation strategy for a particular species one needs information not only on its ecological characteristics but also its genetic variability. There are no population genetic data on the geographical races of C. subrosea in the literature. In this study we examined allozyme polymorphism in, and morphometric data for, three isolated populations of this species in Central European peat bogs to determine whether these local populations have diverged genetically. The investigated peat bogs are ancient habitat islands of high conservation value.

\section{MATERIAL AND METHODS}

\section{Study sites}

One hundred and thirty adult males were collected at the three sites in Central Europe (Fig. 1): (1) Staré Splavy near Mimoň

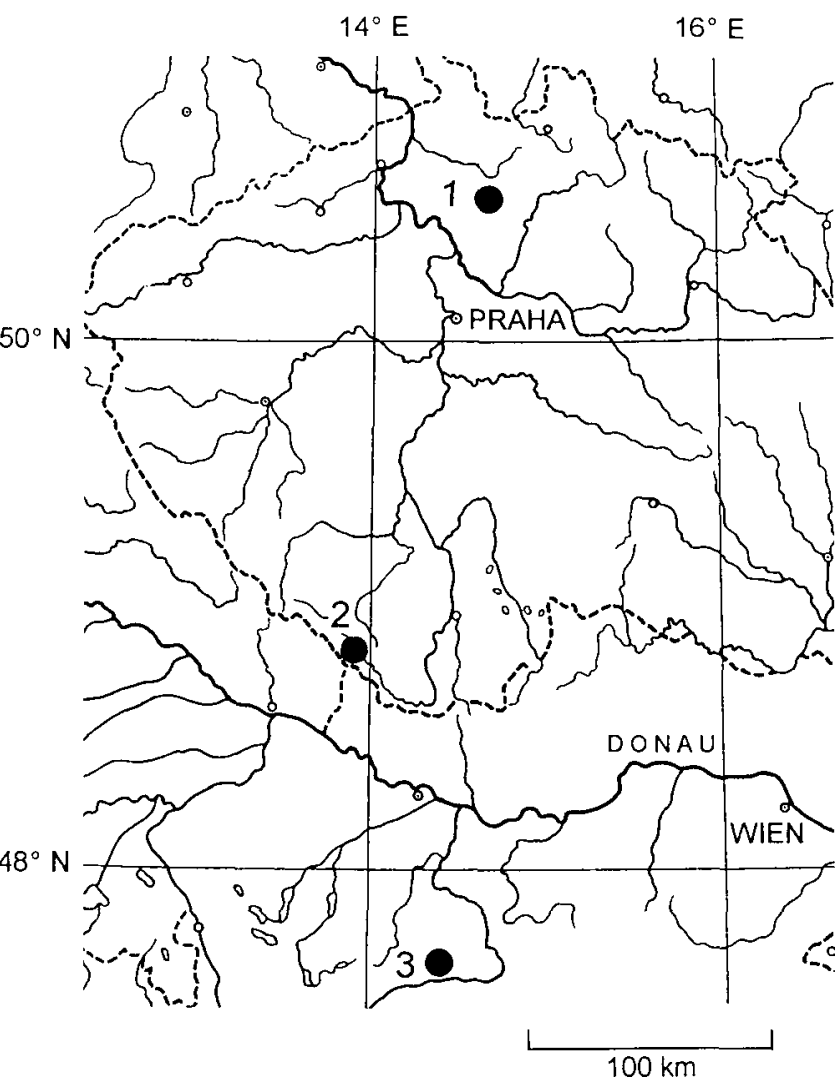

Fig. 1. Peat bog localities of C. subrosea studied in Central Europe: 1 - Staré Splavy near Mimoň (North Bohemia), 2 Mrtvý Luh near Volary (South Bohemia), 3 - Pürgschachen Moor near Ardning (Styria, Austria). 
TABLE 1. Allele frequencies for polymorphic loci.

\begin{tabular}{|c|c|c|c|c|c|c|}
\hline \multirow{3}{*}{ Locus } & \multicolumn{6}{|c|}{ Populations } \\
\hline & \multicolumn{2}{|r|}{ Mrtvý Luh } & \multicolumn{2}{|r|}{ Staré Splavy } & \multicolumn{2}{|c|}{ Pürgschachen Moor } \\
\hline & $\mathrm{n}$ & allele frequency & $\mathrm{n}$ & allele frequency & $\mathrm{n}$ & allele frequency \\
\hline $\begin{array}{r}\text { Diaf a }(100) \\
\text { b (128) }\end{array}$ & 38 & 1.000 & 36 & 1.000 & 38 & $\begin{array}{l}0.9605 \\
0.0395\end{array}$ \\
\hline $\begin{array}{r}\text { Est-1 a }(100) \\
\mathrm{b}(107)\end{array}$ & 40 & $\begin{array}{l}0.9625 \\
0.0375\end{array}$ & 31 & $\begin{array}{l}0.6129 \\
0.3871\end{array}$ & 37 & 1.000 \\
\hline $\begin{array}{c}\text { Est-2 a (100) } \\
\mathrm{b}(96)\end{array}$ & 40 & $\begin{array}{l}0.4125 \\
0.5875\end{array}$ & 34 & $\begin{array}{l}0.7647 \\
0.2353\end{array}$ & 34 & $\begin{array}{l}0.7206 \\
0.2794\end{array}$ \\
\hline $\begin{array}{c}\text { Est-3 a (100) } \\
\mathrm{b}(91)\end{array}$ & 37 & $\begin{array}{l}0.5405 \\
0.4595\end{array}$ & 34 & $\begin{array}{l}0.4853 \\
0.5147\end{array}$ & 37 & $\begin{array}{l}0.5405 \\
0.4595\end{array}$ \\
\hline $\begin{array}{c}\text { Est-4 a (100) } \\
\mathrm{b}(89)\end{array}$ & 38 & $\begin{array}{l}0.5789 \\
0.4722\end{array}$ & 32 & $\begin{array}{l}0.7344 \\
0.2656\end{array}$ & 35 & $\begin{array}{l}0.6286 \\
0.3714\end{array}$ \\
\hline $\begin{array}{r}a-G P D a(100) \\
b(133) \\
c(167) \\
d(233)\end{array}$ & 40 & $\begin{array}{c}0.0750 \\
0.9250 \\
0 \\
0\end{array}$ & 35 & $\begin{array}{l}0.3714 \\
0.3857 \\
0.1142 \\
0.1286\end{array}$ & 33 & $\begin{array}{l}0.6212 \\
0.3182 \\
0.0455 \\
0.0152\end{array}$ \\
\hline $\begin{array}{r}G-6-p d \text { a }(100) \\
\mathrm{b}(137)\end{array}$ & 18 & $\begin{array}{l}0.5278 \\
0.4722\end{array}$ & 15 & $\begin{array}{l}0.6000 \\
0.4000\end{array}$ & 37 & $\begin{array}{l}0.4730 \\
0.5270\end{array}$ \\
\hline $\begin{array}{r}H k-1 \text { a }(100) \\
\mathrm{b}(112)\end{array}$ & 26 & $\begin{array}{l}0.8269 \\
0.1731\end{array}$ & 21 & $\begin{array}{l}0.7857 \\
0.2143\end{array}$ & 24 & $\begin{array}{l}0.7292 \\
0.2708\end{array}$ \\
\hline $\begin{array}{r}H k-2 \text { a }(100) \\
\text { b (107) }\end{array}$ & 37 & $\begin{array}{l}0.7703 \\
0.2297\end{array}$ & 13 & $\begin{array}{l}0.6154 \\
0.3846\end{array}$ & 31 & $\begin{array}{l}0.4677 \\
0.5323\end{array}$ \\
\hline $\begin{array}{r}H k-3 \text { a }(100) \\
\text { b (106) }\end{array}$ & 36 & $\begin{array}{l}0.8750 \\
0.1250\end{array}$ & 21 & $\begin{array}{l}0.4524 \\
0.5476\end{array}$ & 32 & $\begin{array}{l}0.6094 \\
0.3906\end{array}$ \\
\hline $\begin{array}{r}\text { Lap a }(100) \\
\mathrm{b}(133) \\
\mathrm{c}(167)\end{array}$ & 41 & $\begin{array}{l}0.3375 \\
0.4250 \\
0.2345\end{array}$ & 36 & $\begin{array}{l}0.3889 \\
0.2917 \\
0.3194\end{array}$ & 36 & $\begin{array}{l}0.4028 \\
0.3472 \\
0.2500\end{array}$ \\
\hline $\begin{array}{r}\text { Sordh a (100) } \\
\mathrm{b}(114) \\
\end{array}$ & 33 & $\begin{array}{l}0.4697 \\
0.5303\end{array}$ & 18 & $\begin{array}{l}0.3889 \\
0.6111 \\
\end{array}$ & 38 & $\begin{array}{l}0.4868 \\
0.5132 \\
\end{array}$ \\
\hline
\end{tabular}

(Hradčanské rybníky), $280 \mathrm{~m}$ a.s.l., lowland valley peat bog, North Bohemia, Czech Republic (Vávra et al., 1996); (2) Mrtvý Luh near Volary, Šumava Mts., $740 \mathrm{~m}$ a.s.l., montane valley peat bog, South Bohemia, Czech Republic (Spitzer \& Novák, 1969), and (3) Pürgschachen Moor near Ardning, $635 \mathrm{~m}$ a.s.l., montane valley peat bog, Styria, Austria (Spitzer et al., 1996).

\section{Electrophoretic analysis}

Approximately 40 males were used for the enzyme analyses. They were frozen and stored at $-80^{\circ} \mathrm{C}$ until electrophoresis was done. Before homogenization forewings were removed for morphometric analysis. Homogenates were made of the thorax plus abdomen of individual moths in $0.1 \mathrm{M}$ Tris $-\mathrm{HCl}$ buffer, $\mathrm{pH}$ 7.5 , containing $20 \%$ glycerol and $0.1 \%$ Triton X-100 using a glass homogenizer with teflon pestle. They were then centrifuged at $10,000 \mathrm{~g}$ for $20 \mathrm{~min}$ at $4^{\circ} \mathrm{C}$. All the samples were electrophoresed on vertical $7 \%$ polyacrylamide slab gels according to the procedures of Williams \& Reisfeld (1964), Davis (1964), or Tris-borate-sulfate system (Allen et al., 1984). Enzyme activities were visualized using methods of Shaw \& Prasad (1970) or Harris \& Hopkinson (1976).

The following enzyme systems were screened: adenylate kinase (Ak, E.C. 2.7.4.3), aldolase (Ald, E.C. 4.1.2.13), aspartate aminotransferase (Aat, E.C. 2.6.1.1), catalase (Cat, E.C. 1.11.1.6), NADH diaphorase (Diaf, E.C. 1.6.99.3), esterase (Est, E.C. 3.1.1.1); fructose-1,6- diphosphatase (F6dp, E.C. 3.1.3.11), fumarase (Fum, E.C. 4.2.1.2), glucose-6-phosphate dehydrogenase $(G-6-p d h$, E.C. 1.1.1.49), glutamate dehydrogenase $(G d h$, E.C. 1.4.1.2), $\alpha$-glycerophosphate dehydrogenase ( $\alpha$-Gpd, E.C. 1.1.1.8), hexokinase ( $H k$, E.C. 2.7.1.1), inosine triphosphatase
(Itp, E.C. 3.6.1.19), isocitrate dehydrogenase (Idh, E.C. 1.1.1.42), lactate dehydrogenase ( $L d h$, E.C. 1.1.1.27), leucine aminopeptidase (Lap, E.C. 3.4.11.2), malate dehydrogenase ( $M d h$, E.C. 1.1.1.37), malic enzyme (Me, E.C. 1.1.1.40), 6phosphogluconate dehydrogenase (6-Pgd, E.C. 1.1.1.44), phosphoglucose isomerase (Pgi, E.C. 5.3.1.9), sorbitol dehydrogenase (Sordh, E.C. 1.1.1.14), succinate dehydrogenase ( $S c d h$, E.C. 1.3.99.1) and xanthine dehydrogenase (Xdh, E.C. 1.2.1.37). Enzymes that gave patterns which were difficult to assign to a genotype, were eliminated from the survey.

Allelic variants or allozyme bands for each locus were marked in the order of increasing anodal mobility, $a$ being the allele with slowest mobility. Relative mobilities of the bands are shown in the Table 1. Genotypic frequencies for each polymorphic locus in each sample were tested for fit to the HardyWeinberg ratios using $\chi^{2}$ goodness-of-fit tests. The observed and

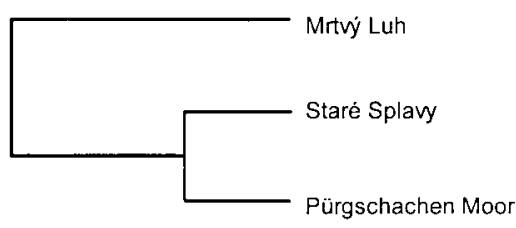

$\begin{array}{ccccc}0.100 & 0.075 & 0.050 & 0.025 & 0.000 \\ & & \text { Genetic Distance } & & \end{array}$

Fig. 2. Dendrogram (unweighted-pair-group method, UPGMA) of the genetic distances between populations of C. subrosea. 
TABLE 2. Heterozygosity statistics for all loci $\left(H_{o}=\text { observed heterozygosity, } H_{e}=\text { expected heterozygosity }\right)^{\prime}$.

\begin{tabular}{|c|c|c|c|c|c|c|}
\hline \multirow{2}{*}{ Locus } & \multicolumn{2}{|c|}{ Mrtvý Luh } & \multicolumn{2}{|c|}{ Staré Splavy } & \multicolumn{2}{|c|}{ Pürgschachen Moor } \\
\hline & $\mathrm{H}_{0}$ & $\mathrm{H}_{\mathrm{e}}$ & $\mathrm{H}_{0}$ & $\mathrm{H}_{\mathrm{e}}$ & $\mathrm{H}_{0}$ & $\mathrm{H}_{\mathrm{e}}$ \\
\hline Aat & 0 & 0 & 0 & 0 & 0 & 0 \\
\hline Itp & 0 & 0 & 0 & 0 & 0 & 0 \\
\hline Diaf & 0 & 0 & 0 & 0 & 0.0789 & 0.0768 \\
\hline Est-1 & 0.0250 & 0.0731 & $0.0645^{* * *}$ & 0.4823 & 0 & 0 \\
\hline Est-2 & 0.6750 & 0.4908 & 0.2941 & 0.3652 & $0.0882 * * *$ & 0.4087 \\
\hline Est-3 & 0.5946 & 0.5035 & 0.5000 & 0.5070 & 0.4865 & 0.5035 \\
\hline$E s t-4$ & $0.1579 * * *$ & 0.4940 & $0.1562 * * *$ & 0.3963 & 0.2857 & 0.4737 \\
\hline$F-6-d p$ & 0 & 0 & 0 & 0 & 0 & 0 \\
\hline Fum & 0 & 0 & 0 & 0 & 0 & 0 \\
\hline$a-G p d$ & $0.0000 * * *$ & 0.1405 & $0.4571^{* * *}$ & 0.6936 & $0.0606^{* * *}$ & 0.5184 \\
\hline$G-6-p d$ & 0.7222 & 0.5127 & $0.1333^{*}$ & 0.4966 & 0.5676 & 0.5054 \\
\hline$H k-1$ & 0.1923 & 0.2919 & $0.1429^{*}$ & 0.3449 & 0.2917 & 0.4034 \\
\hline$H k-2$ & 0.2432 & 0.3588 & 0.1538 & 0.4923 & 0.4839 & 0.5061 \\
\hline$H k-3$ & $0.0833^{*}$ & 0.2218 & $0.1429 * *$ & 0.5075 & 0.5312 & 0.4836 \\
\hline Lap & 0.7000 & 0.6573 & $0.9722 * *$ & 0.6710 & $0.8056^{* * *}$ & 0.6639 \\
\hline$M e$ & 0 & 0 & 0 & 0 & 0 & 0 \\
\hline Scdh & 0 & 0 & 0 & 0 & 0 & 0 \\
\hline Sordh & 0.6970 & 0.5058 & 0.4444 & 0.4889 & 0.5526 & 0.5063 \\
\hline Mean & 0.2273 & 0.2361 & 0.0000 & 0.3025 & 0.2351 & 0.2805 \\
\hline St. Dev. & 0.2976 & 0.2393 & 0.2582 & 0.2622 & 0.2677 & 0.2553 \\
\hline
\end{tabular}

'Expected homozygosity and heterozygosity were computed using Levene (1949). Statistically significant difference ( $\chi^{2}$ goodnessof-fit test): ${ }^{*} \mathrm{P} \leq 0.05,{ }^{*} * \mathrm{P} \leq 0.01$, and ${ }^{* * *} \mathrm{P} \leq 0.001$.

expected heterozygosity $\left(H_{0}\right.$ and $H_{e}$, respectively) were calculated according to Nei (1973) with the correction for small samples (Levene, 1949). The genetic identity I and genetic distance D were calculated using Nei's (1978) formula. Subsequent UPGMA (Sneath \& Sokal, 1973) was used in a cluster analysis. The genetic differentiation among populations and fixation indices $F_{\mathrm{ST}}, \mathrm{F}_{\mathrm{IS}}$ and $\mathrm{F}_{\mathrm{IT}}$ have been analysed according to Nei (1987) by Wright's (1978) F-statistics. All calculations were performed using Popgene programme (Yeh et al., 1997).

Morphometric analyses were carried out manually, using a binocular microscope and a ruler to measure the linear dimen-

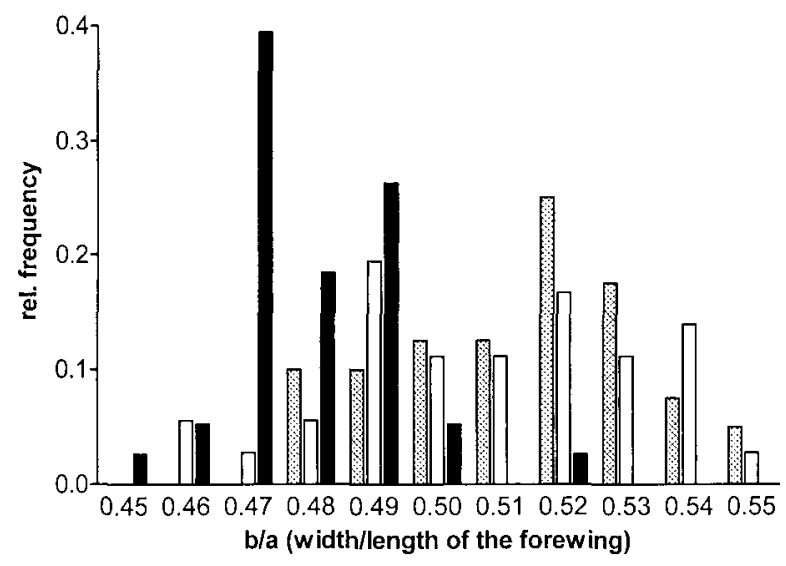

Fig. 3. Relative frequency distributions of the ratio of the width to length of the forewing of populations of $C$. subrosea. Staré Splavy - open bars, Mrtvý Luh - hatched bars, Pürgschachen Moor - solid bars. The difference between populations was significant (ANOVA: $F_{2, m}=36.83, P<0.0001$ ), in that the population at Pürgschachen Moor differed significantly from the other populations at $P<0.05$ (Newman-Keuls multiple comparison test). sions of forewings (length, width, frenulum). Three categories of colour of the forewings was used as a surface character: red, grey and intermediate (see Fig. 4). These data were analysed by one-way ANOVA and Newman-Keuls multiple comparison test using the PRISM graphics programme (GraphPad Software, San Diego, CA, USA).

\section{RESULTS}

Twenty three enzyme systems were tested. Twelve enzyme loci: Diaf, Est, $\alpha-G p d, G 6 p d, H k$, Lap, and Sordh were polymorphic and six other loci: Aat, F6dp, Fum, Itp, Me, Scdh, were monomorphic. Ak, Ald, Pgi, Idh, 6-Pgd were not included in the analysis because of poor or no colour reaction with the stain. Poor resolution of Cat, Est-5, Est-6, Gdh, Mdh and $X d h$ on gels did not allow a reliable analysis. The Est was the most polymorphic enzyme with six allozymes. On the other hand, Diaf was polymorphic in only one population.

The allozyme frequencies for polymorphic loci are presented in Table 1. The observed and expected heterozygosities for single loci are presented in Table 2 (including monomorphic loci). Significant deviations of genotype frequencies from Hardy-Weinberg expectations were observed at some polymorphic loci within populations.

Results of the estimates of Nei's (1987) fixation indices are shown in Table 3. Among the populations, analysis of the variance in allele frequency $\left(\mathrm{F}_{\mathrm{ST}}\right)$ showed significant differentiation (mean $\mathrm{F}_{\mathrm{ST}}=0.0675$ ) at five of the 18 loci. The fixation index value $\left(\mathrm{F}_{\mathrm{IS}}\right)$ measures the deviation from the proportion of heterozygotes expected for each locus (Table 3 ). A negative value of $F_{I S}$ which indicates more heterozygotes than expected, was found for Diaf, Est-3, Lap and Sordh, with that for the first two loci being 

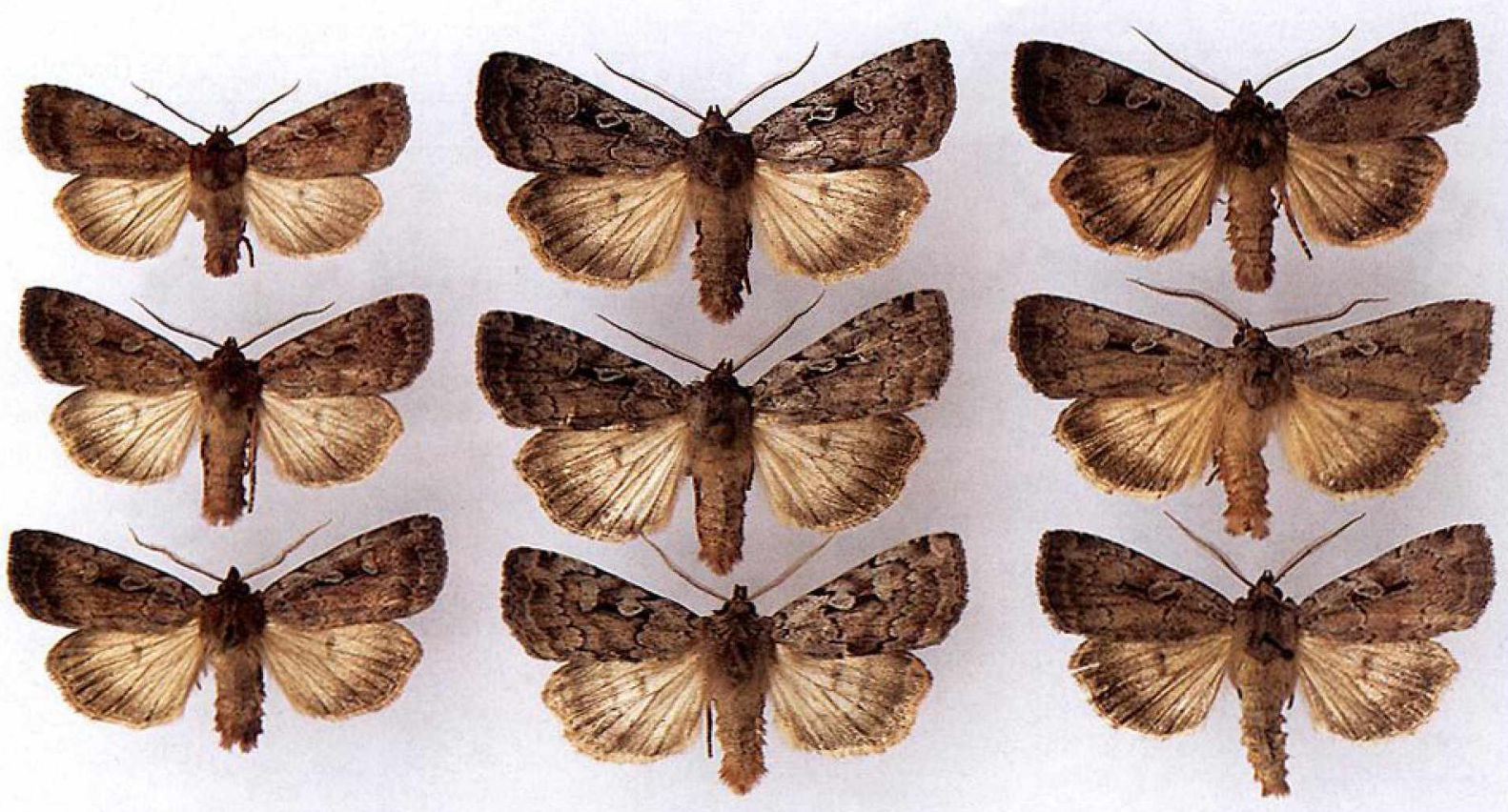

Fig. 4. "Geographical races" of C. subrosea in Central Europe, columns from left to right: Pürgschachen Moor (Austria), Mrtvý Luh (South Bohemia) and Staré Splavy (North Bohemia).

low. For the other loci, the value of $F_{\text {IS }}$ was positive and the average value was relatively high, 0.187 .

A comparison of the populations using all 18 enzyme loci was made to establish genetic identity and genetic distance values. Genetic identity values (Table 4 , above diagonal) showed that all populations were genetically differentiated. Moths from North Bohemia and Styria (Austria) were the most similar to each other $(I=0.981)$, and those that showed the greatest genetic distance were from North Bohemia and the Šumava Mts (South Bohemia) $(D=0.0505)$ (Table 4, below diagonal). There was no apparent association between geographic distance and either genetic distance or mean observed heterozygosity (linear regression, the slopes differ non-significantly from zero $-P=0.929$ and $P=0.235$, respectively). A dendrogram based on unweighted-pair-groups of the arithmetic averages of genetic distances is presented in Fig. 2. This revealed that the Šumava Mts population is clearly distinct from the other two populations.

Morphometric analysis revealed differences in some of the dimensions of the forewing in C. subrosea (Table 5, Fig. 3) in the three populations. The population from Styria (Pürgschachen Moor) differs from both Bohemian populations in the length and width of the forewing and in the ratio of these dimensions. It is the most distinct population morphologically. The proportion of individuals with greyish coloured forewing is significantly higher in the North and South Bohemian populations, and with a reddish pattern in the Styrian population (Fig. 4). In all three populations a small portion of moths have a reddishgrey forewing.

\section{DISCUSSION}

One of the main objectives of population genetics is to determine the genetic variability in populations and to un-

TABLE 3. Summary of F-statistics for polymorphic loci in three populations of the moth.

\begin{tabular}{lcccccc}
\hline Locus & Sample size & $F_{\mathrm{IS}}$ & $\mathrm{F}_{\mathrm{IT}}$ & $\mathrm{F}_{\mathrm{ST}}$ & $\chi^{2}(\mathrm{df})$ & $p$ \\
\hline Diaf & 224 & -0.041 & -0.013 & 0.0267 & $5.9214(2)$ & 0.0518 \\
Est -1 & 216 & 0.8363 & 0.8772 & 0.2501 & $55.1115(2)$ & $<0.001$ \\
Est-2 & 216 & 0.1522 & 0.2418 & 0.1056 & $23.5930(2)$ & $<0.001$ \\
Est-3 & 216 & -0.059 & -0.056 & 0.003 & $0.0570(2)$ & 0.752 \\
Est-4 & 210 & 0.5539 & 0.5621 & 0.0184 & $3.7490(2)$ & 0.1534 \\
$a-G p d$ & 216 & 0.6116 & 0.699 & 0.2251 & $86.6796(6)$ & $<0.001$ \\
G-6-pd & 140 & 0.0365 & 0.047 & 0.0109 & $1.4142(2)$ & 0.4931 \\
Hk-1 & 142 & 0.3842 & 0.39 & 0.009 & $1.4034(2)$ & 0.4957 \\
Hk-2 & 162 & 0.3352 & 0.3782 & 0.0646 & $13.2672(2)$ & 0.001 \\
Hk-3 & 178 & 0.3636 & 0.4483 & 0.133 & $24.0400(2)$ & $<0.001$ \\
Lap & 224 & -0.2607 & -0.251 & 0.008 & $3.4770(4)$ & 0.4814 \\
Sordh & 178 & -0.15 & -0.1415 & 0.007 & $0.9778(2)$ & 0.6133 \\
\hline Mean & 204 & 0.1867 & 0.2376 & 0.0675 & & \\
\hline
\end{tabular}


TÁ31.: 4. Nei's unbiased estimate of genetic identity (above diagonal) and genetic distance (below diagonal) for three populations of C. subrosea.

\begin{tabular}{lccc}
\hline pop ID & 1 & 2 & 3 \\
\hline (1) Mrtvý Luh & $* * * *$ & 0.9507 & 0.9571 \\
(2) Staré Splavy & 0.0505 & $* * * *$ & 0.9812 \\
(3) Pürgschachen Moor & 0.0439 & 0.019 & $* * * *$ \\
\hline
\end{tabular}

derstand mechanisms that maintain or reduce this variability. The populations of $C$. subrosea have mean observed heterozygosities of $0.192-0.245$ which are in the range of values reported for most other Lepidoptera - for instance, for Maniola jurtina (L.) the values range from 0.148 to 0.280 with a mean of 0.218 (Goulson, 1993), for Operophtera brumata (L.) 0.146-0.279 (San \& Šula, 1993) and for Heliothis zea Boddie 0.270 (Sluss et al., 1978). The values are also similar to those commonly found in some forest Lepidoptera, 0.22-0.30 (Mitter \& Futuyma, 1979). However, values as low as 0.083 have been reported for nine Yponomeuta species (Menken, 1982). The average heterozygosity of the populations from South Bohemia (Šumava Mts) and Styria (0.241 and 0.245 , respectively) did not differ significantly from that of the North Bohemian population $(0.192)$. The low average heterozygosity of the latter population may be a consequence of it being a tenth of the size of the other populations and, therefore, more subject to the effect of drift and bottlenecks both of which tend to reduce variability. Descimon \& Napolitano (1993) found that in the endangered sedentary butterfly Parnassius mnemosyne (L.) which often occurs at disjunct colonics, the area of habitat is the most reliable geographical indicator of genetic diversity.

On average, approximately only $6.8 \%$ (mean $\mathrm{F}_{\mathrm{si}}=$ 0.0675 , Table 2) of the total variance of allele frequencies was due to genetic differences between the populations of C. subrosea. Thus $93.2 \%$ of the genetic diversity (heterozygosity) is present in each of the populations. The $C$. subrosea $\mathrm{F}_{\mathrm{ST}}$ value of 0.0675 is higher than most of the values reported for mobile butterflies and moths; e.g. 0.009 in migratory Danaus plexippus (L.) (Eanes \& Koehn, 1978), 0.005-0.021 in M. jurtina (L.) (Goulson 1993), and 0.027 in Yponomeuta (Menken, 1982), though values as high as 0.083 for non-migratory ("hostassociated") populations of Zeiraphera diniana Guenée (Emelianov et al., 1995) and 0.154 for Feltia jaculifera (Guenée) (Gooding et al. 1992) have been reported. In more sedentary species, the $F_{S T}$ values are on average usually higher, as in $P$. mnemosyne populations from Hungary (Meglécz et al., 1997) and France (Napolitano \& Descimon, 1994); 0.064 and 0.135 , respectively.

The fixation indices $\left(F_{I T}\right.$ and $F_{I S}$ ) computed for each individual locus showed persistent heterozygote deficiency at loci Est-1, Est-2, Est-4, a-GPD, G-6-pd and all $H k$ (both $F_{\mathrm{IT}}$ and $\mathrm{F}_{\mathrm{IS}}>0$ ) and heterozygote excess at loci Diaf, Est-3, Lap and Sordh (both $\mathrm{F}_{\mathrm{IT}}$ and $\mathrm{F}_{\mathrm{IS}}<0$ ). Thus, genetic variability at the twelve polymorphic enzyme loci indicates significant deviation from the expected number of heterozygotes. This may be due to selection, subdivision of populations or inbreeding. The simultaneous occurrence of a deficit and excess of heterozygotes at various polymorphic loci hint at both substructuring and selection in the moth populations. The possibility of inbreeding as a cause of prevailing homozygote excess cannot be excluded because of small population size, however if this were the case one would expect all loci to be affected similarly.

The degree of genetic differentiation between the populations of the moth (mean $\mathrm{D}=0.038$ ) is comparable to values found in other species. The mean genetic distance between 11 populations of Heliothis virescens (F.) is 0.034 (Sluss \& Graham, 1979), for fourteen populations of $M$. jurtina (Goulson, 1993) it varies between 0 and 0.013 , and in conspecific populations of Yponomeuta species it ranges from 0.000 to 0.023 , with a mean of 0.006 (Menken, 1981). On the other hand, the genetic distance between two closely related Brenthis species (Nymphalidae) is only 0.043 (Matsuoka et al., 1983). Taking into account that the $C$. subrosea populations are, in contrast to the above-mentioned examples, geographically and reproductively isolated populations, the mean genetic distance is not very high.

There was no apparent association between genetic hetcrozygosity and the geographical distance between the three isolated populations of $C$. subrosea. Such association was only observed in the case of wing colour. The absence of an association between genetic heterozygosity in enzyme loci and geographical distance is not exceptional, e.g., some populations of $M$. jurtina more than 150 $\mathrm{km}$ apart are genetically identical, while others only $1 \mathrm{~km}$ apart are at the upper range of values of D (Goulson, 1993). Meglécz et al. (1997) obtained similar results for populations of $P$. mnemosyne in North-East Hungary. In $C$. subrosea, the most likely factor accounting for the divergence in the populations is separate colonization of the peat bog localities in early Holocene (cf. Spitzer \& Novák, 1969; Jankovská, 1980; Spitzer, 1994). The mor-

TABl.1: 5. Forewing dimensions of C. subrosea.

\begin{tabular}{lccc}
\hline Dimension & Mrtvý Luh & Staré Splavy & Pürgschachen Moor \\
\hline forewing length (a) & $18.54 \pm 0.56$ & $18.35 \pm 0.62$ & $17.54 \pm 0.53^{*}$ \\
forewing width (b) & $9.53 \pm 0.42$ & $9.27 \pm 0.52$ & $8.42 \pm 0.32^{*}$ \\
b/a & $0.514 \pm 0.019$ & $0.509 \pm 0.024$ & $0.479 \pm 0.013^{*}$ \\
length of frenulum (c) & $3.250 \pm 0.171$ & $3.339 \pm 0.221$ & $3.194 \pm 0.191$ \\
c/a & $0.0277 \pm 0.0014$ & $0.0277 \pm 0.0018$ & $0.0273 \pm 0.0012$ \\
\hline
\end{tabular}

$* \mathrm{P} \leq 0.001$. 
phometric characteristics, colour patterns of the forewings, and enzyme variation support the hypothesis of a high specificity of each local peat bog population associated with unique habitat islands and conform to old ideas (eg. Warnecke, 1926, 1952) of specific geographical races ("subspecies") of C. subrosea. Each isolated population is very dependent on its local habitat conservation.

ACKNOWLEDGEMENTS. We thank J. Jaroš for his help in collecting live material, and R. Gutwirthová and H. Zikmundová for their technical assistance. We also thank F. Marec and two anonymous referees for critically reading the manuscript and helpful suggestions. This study was supported by grant No. 206/97/0077 of the Grant Agency of the Czech Republic and by Ost-West Projekt Nr. 41 of the Austrian Academy of Sciences.

\section{REFERENCES}

Allen R.C., Saravis C.A. \& Maurer H.R. 1984: Gel Electrophoresis and Isoelectric Focusing of Proteins. Walter de Gruyter, Berlin, $255 \mathrm{pp}$.

Davis B.J. 1964: Disc electrophoresis II. Method and application to human serum proteins. Ann. N. Y. Acad. Sci. 121: 404-427.

Descimon H. \& Napolitano M. 1993: Enzyme polymorphism, wing pattern variability, and geographical isolation in an endangered butterfly species. Biol. Conserv. 66: 117-123.

EANES W.F. \& KoEIIN R.K. 1978: An analysis of genetic structure in the monarch butterfly, Danaus plexippus L. Evolution 32: 784-797.

Emelianov I., Mallet J. \& Baltensweiler W. 1995: Genetic differentiation in Zeiraphera diniana (Lepidoptera: Tortricidae, the larch budmoth): polymorphism, host races or sibling species? Heredity 75: 416-424.

Gooding R.H., Rolsetu B.M., Byers J.R. \& Herle C.E. 1992: Electrophoretic comparisons of pheromotypes of the dingy cutworm, Feltia jaculifera (Gn.) (Lepidoptera: Noctuidae). Can. J. Zool. 70: 79-86.

Goulson D. 1993: Allozyme variability in the butterfly, Maniola jurtina (Lepidoptera: Satyrinae) (L.): evidence for selection. Heredity 71: 386-393.

HARRIS H. \& Hopkinson D.A. 1976: Handbook of Enzyme Electrophoresis in Human Genetics. North Holland Publishing Company, Amsterdam, 473 pp.

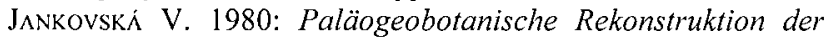
Vegetationsentwicklung im Becken Treboňská pánev während des Spätglazials und Holozäns. Academia, Praha, 151 pp.

LEVENE H. 1949: On a matching problem arising in genetics. Ann. Math. Stat 20: 91-94.

Matsuoka N., Chiba Y. \& Satroh K. 1983: Allozymic similarity in two species of the genus Brenthis (Lepidoptera: Nymphalidae). Comp. Biochem. Physiol. (B) 74: 385-387.

Meglécz E., Pecsenye K., Peregovits L. \& Varga Z. 1997: Allozyme variation in Parnassius mnemosyne (L.) (Lepidoptera) populations in North-East Hungary: variation within a subspecies group. Genetica 101: 59-66.

MENKEN S.B.J. 1981: Host races and sympatric speciation in small ermine moths. Entomol. Exp. Appl. 30: 280-292.

MENKEN S.B.J. 1982: Biochemical genetics and systematics of small ermine moths (Lepidoptera, Yponomeutidae). Z. Zool. Syst. Evolutionsforsch. 20: 131-143.

Mikkola K. \& Spirzer K. 1983: Lepidoptera associated with peatlands in central and northern Europe: a synthesis. Nota Lepidopterol. 6: 216-229.

MitTer C. \& Futuyma D.J. 1979: Population genetic consequences of feeding habits in some forest Lepidoptera. Genetics 92: 1005-1021.
Napolitano M. \& Descimon H. 1994: Genetic structure of French populations of the mountain butterfly Parnassius mnemosyne L. (Lepidoptera: Papilionidae). Biol. J. Linn. Soc. 53: 325-341.

NЕı M. 1973: Analysis of gene diversity in subdivided populations. Proc. Natn. Acad. Sci. USA 70: 3321-3323.

NEI M. 1978: Estimation of average heterozygosity and genetic distance from a small number of individuals. Genetics 89: 583-590.

NeI M. 1987: Molecular Evolutionary Genetics. Columbia University Press, New York, $574 \mathrm{pp}$.

Peus F. 1932: Die Tierwelt der Moore unter besonderer Berücksichtigung der europäischen Hochmoore. Handb. Moorkunde 3. Borntraeger, Berlin, $277 \mathrm{pp}$.

SAN N.V. \& ŠULA J. 1993: Allozyme variation in the winter moth, Operophtera brumata (Lepidoptera: Geometridae), in isolated populations. Eur. J. Entomol. 90: 303-310.

SHAW C.R \& PRASAD R. 1970: Starch gel electrophoresis of enzyme - a compilation of recipes. Biochem. Genet. 4: $297-320$.

Sluss T.P. \& Granım H.M. 1979: Allozyme variation in natural populations of Heliothis virescens. Ann. Entomol. Soc. Am. 72: $317-322$

Sluss T.P., Sluss E.S., Grailam H.M. \& DuBois M. 1978: Allozyme differences between Heliothis virescens and $\mathrm{H}$. zea. Ann. Entomol. Soc. Am. 71: 191-195.

SNeATh P.H.A. \& SOKAL R.R. 1973: Principles of Numerical Taxonomy. 2nd ed. Freeman, San Francisco, $324 \mathrm{pp}$

SPITZER K. 1994: Biogeographical and ecological determinants of the central European peat bog Lepidoptera: The habitat island approach to conservation. Nota Lepidopterol. (Suppl.) 5: $45-49$.

SPitzer K. \& Novík I. 1969: Eugraphe subrosea Steph. (Lep., Noctuidae) in Böhmen und zoogeographische Bemerkungen über den Ursprung ihrer gegenwärtigen Verbreitung in Europa. Acta Entomol. Bohemoslov. 66: 109-114.

Spitzer K., Jaroš J., Licuttenberger F. \& Malicky H. 1996: Die Biodiversität der Schmetterlingsfauna des Pürgschachenmoores im steirischen Ennstal und ihr Schutzwert. Z. Arb. Gem. Öst. Entomol. 48: 87-97.

Tillotson I.J.L. \& SPITZER K. 1998: The Rosy marsh moth, Coenophila subrosea (Stephens, 1829) (Lepidoptera: Noctuidae) a review of its bionomics, distribution and conservation status with special reference to Britain. Entomol. Gaz. 49: 75-89.

VÁvra J., Novík I., LıŠkA J. \& Skyva J. 1996: Motýlí fauna př́rodní rezervace "Hradčanské rybníky" u Mimoně (Lepidoptera). [Lepidopteran fauna of the nature reserve "Hradčanské rybníky" near Mimoň (Lepidoptera)]. Klapalekiana 32: 89-121 (in Czech, English abstr.).

WARNECKE G. 1926: Agrotis subrosea Steph. auf dem europäischen Festland, ihre Formen, ihre Verbreitung und ihre Biologie. Entomol. Z. Frankf. a. M. 40: 173-189.

WARNECKE G. 1952: Eugraphe (Agrotis) subrosea Steph.: Die Unterschiede der österreichischen Lokalform kieferi Reb. und der nordwestdeutschen rubrifera Warn. Z. Wiener Entomol. Ges. 37: 81-84.

Williams D.E. \& Reisfeld R.A. 1964: Disc electrophoresis in polyacrylamide gels: extension to new conditions of $\mathrm{pH}$ and buffer. Ann. N. Y. Acad. Sci. 121: 373-381.

Wriglit S. 1978: Evolution and the Genetics of Populations. Vol. 4. Variability Within and Among Natural Populations. University of Chicago Press, Chicago, $580 \mathrm{pp}$.

YeII F.C., YAnG R.-C., Boyle T.B.J., Ye Z.-H. \& MAO J.X. 1997: Popgene, the user-friendly shareware for population genetic analysis. Molecular Biology and Biotechnology Centre, University of Alberta, Canada.

Received June 4, 1999; accepted September 29, 1999 